\title{
Role of TLR2 and TLR4 in Human Neutrophil Functions Against Paracoccidioides brasiliensis
}

\author{
M. J. Acorci-Valério*, A. P. Bordon-Graciani*, L. A. Dias-Melicio*, M. de Assis Golim†', E. Nakaira-

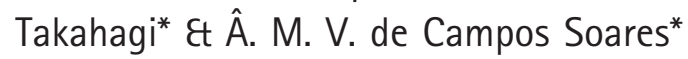

*Department of Microbiology and Immunology, Biosciences Institute, São Paulo State University, Botucatu, S.P., Brazil; and $\dagger$ Botucatu Blood Center, School of Medicine, São Paulo State University, Botucatu, S.P., Brazil

Received 7 July 2009; Accepted in revised form 28 October 2009

Correspondence to: Ângela Maria Victoriano de Campos Soares, PhD, Department of Microbiology and Immunology, Biosciences Institute, São Paulo State University, Botucatu, CEP 18618-000, S.P., Brazil. E-mail: acsoares @ibb.unesp.br

\section{Introduction}

Paracoccidioides brasiliensis $(\mathrm{Pb})$ is the aetiological agent of paracoccidioidomycosis, a systemic mycosis endemic in Latin America. The infection can be acquired by inhalation of airborne conidia that reach the lung alveoli, where they transform into yeast cells, the infective form [1]. Many people are exposed to the fungus, but only a small number develop clinical symptoms, suggesting that both innate and adaptive mechanisms are important in fungus clearance [2-5]. The host innate immune response against fungus has been well characterized, and several studies have clearly shown the role of phagocytic cells. In this context, in last years, various studies have focused on the role of neutrophils [6].

Some in vitro studies suggest that $\mathrm{Pb}$-infected macrophages induce the onset of extravascular neutrophilia by releasing chemotactic peptides [7]. Heavy neutrophil infiltration in the lungs of $\mathrm{Pb}$-infected mice at early acute infection was correlated with the release of keratinocytederived chemokine $(\mathrm{KC})$ and macrophage inflammatory protein-1 $\alpha$ (MIP-1 $\alpha$ ), two important neutrophil chemoattractants [8]. In consequence of these chemotactic processes, massive neutrophil infiltration is found in infected tissues from patients with paracoccidioidomycosis [9] and in the early lesions of experimentally infected animals $[10,11]$.

Neutrophils from infected individuals can kill $\mathrm{Pb}$ [12]. However, experiments using more sensitive methods showed that despite their phagocytic capacity, these neutrophils are unable to digest $\mathrm{Pb}$ in vitro, indicating that a defect of neutrophil function may represent a susceptibility factor [13]. Further, studies in mice strongly suggest that lack of fungicidal activity correlates with defect in neutrophil activation because only those neutrophils from $P$. brasiliensis-sensitized mice exhibited efficient fungicidal 
activity in vitro [14]. In addition, neutrophil fungicidal activity is higher in resistant mice than in susceptible mice [15]. Pina et al. [16], in a complete study of neutrophil depletion during murine infection, have shown that these cells are essential for host defence to $\mathrm{Pb}$ infection and that host genetic pattern exerts an important influence on neutrophil functions.

Together, the findings reported to date clearly demonstrate that neutrophils may play an important effector and immunomodulatory role, especially in the early stages of infection, contributing to $\mathrm{Pb}$ host resistance. Nonetheless, some studies show that neutrophil functions, including fungus killing, require activation with cytokines and other factors. In our laboratory, IFN- $\gamma$, TNF- $\alpha$, granulocytemacrophage colony-stimulating factor (GM-CSF) and IL-15 have been observed to activate human neutrophils for fungicidal activity by a mechanism dependent on $\mathrm{H}_{2} \mathrm{O}_{2}$ and superoxide anion [17, 18].

The specific detection of microorganisms by innate cells is mediated by pattern recognition receptors (PRR), germ line-encoded receptors that recognize microbial structures referred to as pathogen-associated molecular pattern [19]. Toll-like receptors (TLR) are essential PRR that mediate recognition of microbial structures, such as those of fungi, as well as the subsequent inflammatory and adaptative responses [20-23].

Because neutrophils and TLR are respectively the prototypical cell and receptor of innate immune response, the role of individual TLR on neutrophil functions has been investigated [24-27], including that involved in the response of these cells to fungi [28]. Various stimuli have been shown to regulate expression of TLR in neutrophils, including pathogen structures and TLR ligands, such as lipopolysaccharide (LPS), and pro-inflammatory cytokines, such as IL- $1 \beta$, TNF- $\alpha$, GM-CSF and IFN- $\gamma[24,26,29-$ 31]. In view of these observations, studies conducted to evaluate the role of TLR on neutrophil functions against $\mathrm{Pb}$ may contribute to a better understanding of parasite/host relationship in the mycosis. In the present study, we aimed at evaluating TLR2 and TLR4 expression on human neutrophils activated with GM-CSF, IL-15, TNF- $\alpha$ or IFN- $\gamma$ and challenged with $\mathrm{Pb} 18$, a virulent strain of the fungus. Moreover, we asked if these receptors have a role on fungicidal activity, $\mathrm{H}_{2} \mathrm{O}_{2}$ and IL-6, IL-8, TNF- $\alpha$ and IL-10 production by activated and challenged cells.

\section{Subjects and methods}

Healthy individuals. Twenty-eight healthy blood donors from University Hospital of the Botucatu Medical School, São Paulo State University, Brasil (age range 20-50 years) were included in the present work. The study was approved by Ethics Committee of Botucatu Medical School, and informed consent was obtained from all the blood donors.
Fungi. The high virulent strain of $P$. brasiliensis (Pb18) was used throughout this study. To ensure virulence, the isolate was used after three serial animal passages. $\mathrm{Pb} 18$ yeast cells were then maintained by weekly sub-cultivation in the yeast-form cells at $35{ }^{\circ} \mathrm{C}$ on $2 \%$ glucose, $1 \%$ peptone, $0.5 \%$ yeast extract and $2 \%$ agar medium (GPY medium) and used on the sixth day of culture. Yeast cells were washed and suspended in $0.15 \mathrm{M}$ phosphate-buffered saline (PBS $\mathrm{pH}$ 7.2). To obtain individual cells, the fungal suspension was homogenized with glass beads in a Vortex homogenizer (three cycles of $10 \mathrm{~s}$ ). Yeast viability was determined by phase contrast microscopy, and bright yeast cells were counted as viable, while dark ones were considered not viable. Fungal suspensions containing more than $95 \%$ viable cells were used in the experiments.

Isolation of buman neutrophils. Heparinized venous blood samples were obtained from healthy subjects. Ten millilitres of blood was diluted in $10 \mathrm{ml}$ RPMI 1640 tissue culture medium (Sigma-Aldrich, Inc., St Louis, MO, USA.). The cell was layered on Percoll $85 \%$ and Histopaque - 1077 (Sigma-Aldrich). The cell fraction containing neutrophils was washed with RPMI 1640. Remaining cells were suspended in RPMI 1640 tissue culture medium supplemented with $2 \mathrm{~mm}$ of L-glutamine (Sigma-Aldrich), $40 \mathrm{ug} / \mathrm{ml}$ of gentamycin and $10 \%$ heatinactivated autologous human serum (CTCM: complete tissue culture medium). The cellular viability was assessed by trypan blue dye exclusion test, and the suspensions were adjusted for $2 \times 10^{6}$ cells $/ \mathrm{ml}$. The purity of neutrophil suspensions determined by morphological examination of May-Grunwald-Giemsa-stained slides was $>98 \%$. Then, neutrophil suspensions were dispensed into 96-well flat-bottom plates with a volume of $100 \mu \mathrm{l} /$ well and incubated for $18 \mathrm{~h}$ at $37{ }^{\circ} \mathrm{C}$ in a $5 \% \mathrm{CO}_{2}$ only with CTCM, or LPS $(20 \mu \mathrm{g} / \mathrm{ml})$ or the cytokines GM-CSF (100 U/ml), IL-15 (31.2 ng/ml), TNF- $\alpha(250 \mathrm{U} / \mathrm{ml})$ or IFN- $\gamma \quad(50 \mathrm{U} / \mathrm{ml}) \quad(\mathrm{R} \& \mathrm{D}$ Systems, Minneapolis, MN, USA) and then challenged with $\mathrm{Pb} 18$ at the concentration of $2 \times 10^{4}$ yeasts $/ \mathrm{ml}$ of CTCM plus $10 \%$ fresh human autologous serum (1:50 fungus/neutrophils ratio) during $4 \mathrm{~h}$. In the experiments for evaluating fungicidal activity, $\mathrm{H}_{2} \mathrm{O}_{2}$ and cytokines production, neutrophils were treated with anti-TLR2 (clone TL2.1) or anti-TLR4 (clone HTA125) monoclonal antibodies (Imgenex Biocarta US, San Diego, CA, USA) at 0.5 and $10 \mu \mathrm{g} / \mathrm{ml}$, respectively, for $1 \mathrm{~h}$ at $37{ }^{\circ} \mathrm{C}$, before fungus challenge.

TLR2 and TLR4 expression. After Pb18 challenge, neutrophils were evaluated by TLR 2 and TLR 4 expression. This assay was performed by flow cytometry analysis. Neutrophils $\left(1 \times 10^{6}\right.$ neutrophils $\left./ \mathrm{ml}\right)$ were distributed $(500 \mu \mathrm{l})$ into polystyrene tubes for cytometric analysis (BD Labware, San Jose, CA, USA). Cells were washed and incubated with fluorescein isothiocyanateconjugated anti-TLR2 (Biolegend Inc., San Diego, CA, 
USA), phycoerythrin-conjugated anti-TLR4 (Biolegend), according to the instructions of the manufacturer. After incubation for $15 \mathrm{~min}$ at room temperature, the cells were analysed with a FACSCalibur flow cytometer (Becton Dickinson, San Jose, CA, USA). Data (an average of 10,000 events per sample) were analysed with the CELL QUEST Software (Cell Quest Software, San Jose, CA, USA).

Evaluation of fungicidal activity. After $\mathrm{Pb} 18$ challenge, neutrophil-fungus cocultures were harvested by aspiration with sterile distilled water to lyse neutrophils. Washing of each well resulted in a final volume of $2.0 \mathrm{ml}$, and $0.1 \mathrm{ml}$ was plated on supplemented brainheart infusion agar medium (Difco Laboratories, Detroit, MI, USA) plates containing $0.5 \%$ of gentamicin, $4 \%$ horse normal serum and 5\% P. brasiliensis strain 192 culture filtrate ( $\mathrm{vol} / \mathrm{vol})$, the latter being the source of growth-promoting factor. Inoculated plates, in triplicate of each culture, were incubated at $35^{\circ} \mathrm{C}$ in sealed plastic bags to prevent drying. After 10 days, the number of colony forming units (CFU) per plate was counted. The inoculum used for the challenge was also plated according to the same conditions. The plates containing the material obtained from the neutrophil-fungus cocultures were considered as experimental plates, and those plated with the inoculum alone and counted at time zero were used as control plates. Fungicidal activity percentage was determined by the following formula:

$\%$ Fungicidal Activity $=[1-($ mean CFU recovered on experimental plates/mean $\mathrm{CFU}$ recovered on control plates)] $\times 100$.

Evaluation of $\mathrm{H}_{2} \mathrm{O}_{2}$ release. The release of $\mathrm{H}_{2} \mathrm{O}_{2}$ by neutrophils was measured by the horseradish peroxidasephenol red oxidation method [32]. For this assay, neutrophil cultures were challenged with $\mathrm{Pb} 18$ suspension diluted in phenol red buffer containing $50 \mu \mathrm{g} / \mathrm{ml}$ of horseradish peroxidase (type II, Sigma-Aldrich) plus $10 \%$ fresh human $A B$ serum and further incubation for $1 \mathrm{~h}$ in $5 \% \mathrm{CO}_{2}$ at $37{ }^{\circ} \mathrm{C}$ in humidified chamber. The reaction was stopped by addition of $10 \mu \mathrm{l}$ of $1 \mathrm{~N} \mathrm{NaOH}$, and the absorbance at $620 \mathrm{~nm}$ was determined with a microELISA reader (MD 5000; Dynatech Laboratories, Inc., Chantilly, VA, USA). All measurements were repeated four times, and the absorbance was converted into nanomoles of a standard curve of $\mathrm{H}_{2} \mathrm{O}_{2}$.

Measurement of cytokines. After $\mathrm{Pb}$ challenge, neutrophil culture supernatants were separated from cell debris by centrifugation at $1000 \mathrm{~g}$ for $15 \mathrm{~min}$ and stored at $-70{ }^{\circ} \mathrm{C}$. TNF- $\alpha$, IL-6, IL-8 and IL-10 concentrations were measured by capture ELISA using Kit DuoSet (R\&D Systems). ELISA was performed according to the manufacturer's protocol. Cytokine concentrations were determined with reference to a standard curve for serial twofold dilutions of recombinant cytokines. Absorbance values were measured at $492 \mathrm{~nm}$ using a micro-ELISA reader (MD 5000; Dynatech Laboratories).
Statistical analysis. Data were analysed statistically using the INSTAT software (Graph Pad, San Diego, CA, USA). The results were compared by variance analysis (ANOVA) followed by Tukey's test, with the level of significance set at $P<0.05$.

\section{Results}

\section{TLR2 and TLR4 expression}

In the initial set of experiments, we assessed the effect of cytokines activation and/or Pb18 challenge on TLR2 and TLR 4 expression by neutrophils. Before Pb18 challenge, neutrophils were pre-activated with the cytokines GMCSF, IL-15, TNF- $\alpha$ or IFN- $\gamma$ or LPS and evaluated by TLR 2 and TLR 4 expression, using flow cytometry. LPS was used as positive control for TLR2 and TLR 4 expression by neutrophils. Cells treated only with CTCM expressed very low levels of TLR2 that increased after activation with cytokines or LPS. After Pb18 challenge, all cultures expressed higher TLR2 levels when compared to their respective non-challenged cultures (Fig. 1A). All cytokines and LPS increased TLR4 expression. However, after $\mathrm{Pb} 18$ challenge, a decrease in this expression was detected when compared to that detected in non-challenged cells (Fig. 1B). Together, the results showed that neutrophil activation with all cytokines resulted in an increase in TLR2 and TLR4 expression. However Pb18 modulation was different for TLR2 or TLR4. While this fungus increased TLR2 expression inducing an additional effect to that of cytokines, it decreased TLR 4 expression.

\section{Role of TLR2 and TLR4 on fungicidal activity}

As all cytokines increased TLR2 and TLR 4 expression, we performed experiments to assess the role of these receptors on antifungal activities by activated neutrophils, such as fungicidal activity, $\mathrm{H}_{2} \mathrm{O}_{2}$ release and IL-6, IL-8, TNF- $\alpha$ and IL-10 production. For this, before fungus challenge, neutrophils were treated with anti-TLR2 or anti-TLR 4 monoclonal antibodies, for TLR 2 and TLR 4 blockade. Parallel experiments confirmed inhibition of TLR 2 and TLR 4 expression after blockade (data not presented). Figure 2 shows the results on fungicidal activity. Non-activated cells presented a very low fungicidal activity. However, this activity was significatively increased after cells activation with all cytokines. Interestingly, this response profile was not significatively altered after TLR2 or TLR 4 blockade, leading us to suggest that these receptors were not involved in this activity.

\section{Role of TLR2 and TLR4 on $\mathrm{H}_{2} \mathrm{O}_{2}$ production}

Figure 3A-D show the results concerning TLR2 and TLR 4 role on $\mathrm{H}_{2} \mathrm{O}_{2}$ production by neutrophil activated 

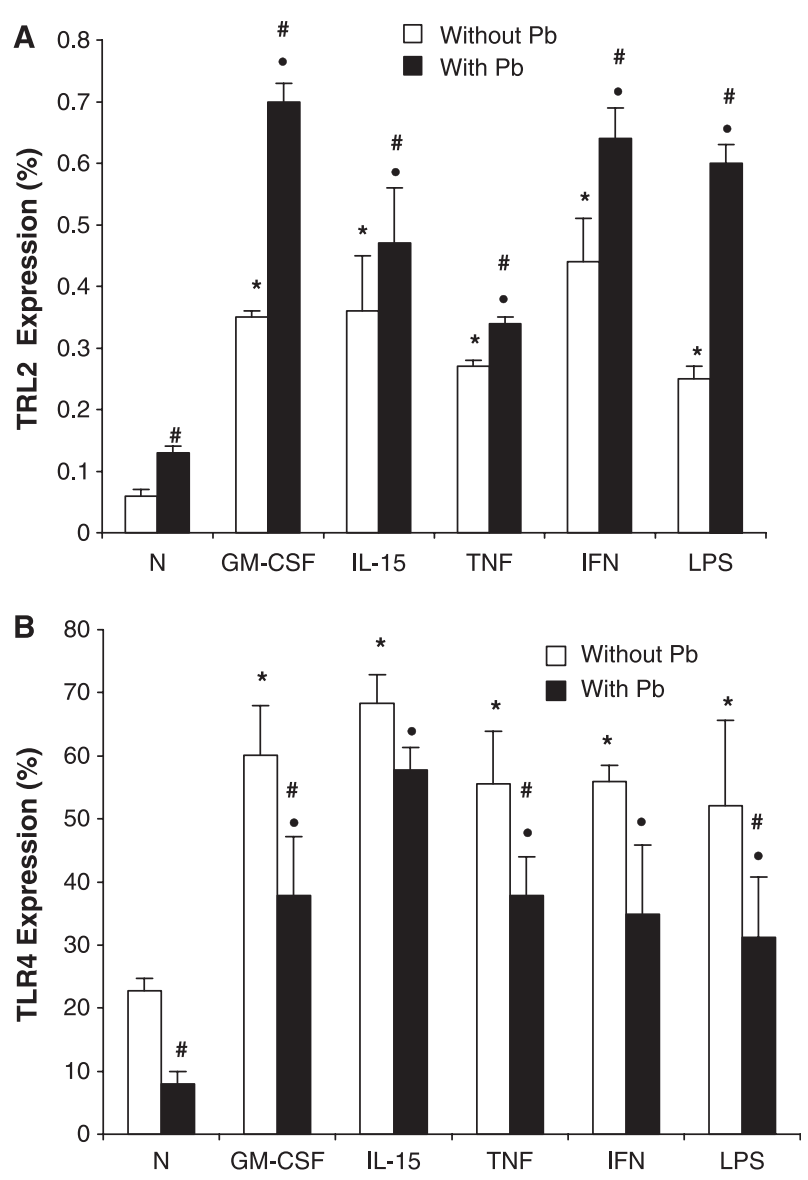

Figure 1 TLR2 (A) and TLR4 (B) expression by human neutrophils. Cells were non-activated $(\mathrm{N})$ or activated with the cytokines GM-CSF $(100 \mathrm{U} / \mathrm{ml}), \quad$ IL-15 $(31.2 \mathrm{ng} / \mathrm{ml})$, TNF- $\alpha(250 \mathrm{U} / \mathrm{ml})$ or IFN- $\gamma$ $(50 \mathrm{U} / \mathrm{ml})$ or LPS $(20 \mu / \mathrm{ml})$ for $18 \mathrm{~h}$, challenged or not with Pb18 for $4 \mathrm{~h}\left(2 \times 10^{4}\right.$ yeasts/ml: 1:50 fungus/PMN ratio $)$ and evaluated by TLR 2 and TLR 4 expression by flow cytometry. The figure shows the mean \pm SEM obtained from 25 blood donors. Statistically significant differences between groups are indicated. $* P<0.05$ versus $\mathrm{N}$; $\bullet P<0.05$ versus $\mathrm{N}+\mathrm{Pb} ; \# P<0.05$ versus $\mathrm{N}$ without $\mathrm{Pb}$.

with GM-CSF, IL-15, TNF- $\alpha$ or IFN- $\gamma$, respectively. A similar response profile was detected for all assays, because $\mathrm{H}_{2} \mathrm{O}_{2}$ levels were significatively increased after activation with the four cytokines, but differences among them not being detected. Moreover, there was a tendency towards $\mathrm{Pb} 18$ to increase metabolite release and to induce an additional effect to that of cytokines (data not statistically significant). However, as detected for fungicidal activity, $\mathrm{H}_{2} \mathrm{O}_{2}$ release was not significatively altered with TLR2 or TLR 4 blockade showing the non-involvement of these receptors on this neutrophil activity.

\section{Participation of TLR2 and TLR4 on IL-6, IL-8, TNF- $\alpha$ and IL-10 production}

We also studied the possible role of TLR2 and TLR 4 on IL-6, IL-8, TNF- $\alpha$ and IL-10 production by human

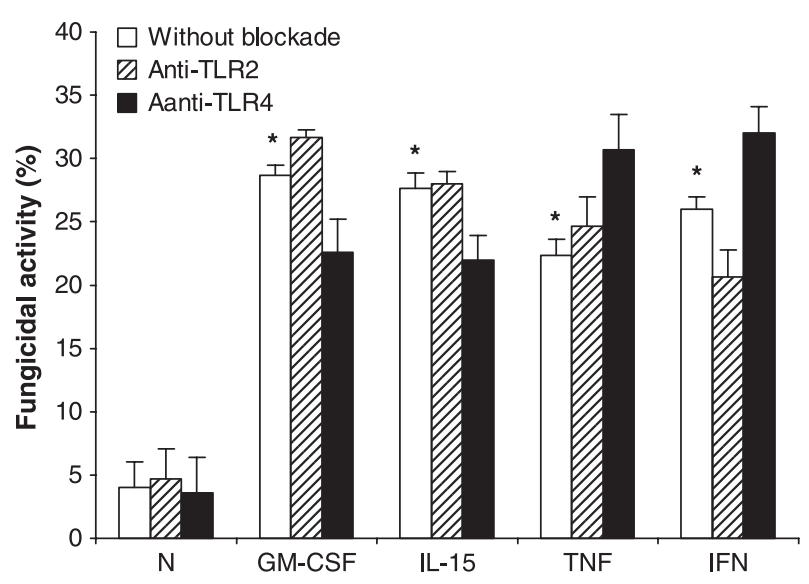

Figure 2 Role of TLR2 and TLR 4 on fungicidal activity. Cells were non-activated $(\mathrm{N})$ or activated with the cytokines GM-CSF $(100 \mathrm{U} / \mathrm{ml})$, IL-15 $(31.2 \mathrm{ng} / \mathrm{ml})$, TNF- $\alpha(250 \mathrm{U} / \mathrm{ml})$ or IFN- $\gamma(50 \mathrm{U} / \mathrm{ml})$, in the absence or presence of anti-TLR 2 or anti-TLR 4 monoclonal antibodies, challenged or not with $\mathrm{Pb} 18$ for $4 \mathrm{~h}\left(2 \times 10^{4}\right.$ yeasts $/ \mathrm{ml}: 1: 50$ fungus/PMN ratio) and evaluated for fungicidal activity. The figure shows the mean \pm SEM obtained from 25 blood donors. Statistically significant differences between groups are indicated. $* P<0.05$ versus $\mathrm{N}$ without anti-TLR2 or anti-TLR4.

neutrophils activated with the different cytokines and Pb18 challenged. IL-6 and IL-8 were not detected in neutrophil supernatants. Then, Figs. $4 \mathrm{~A}-\mathrm{E}$ and $5 \mathrm{~A}-\mathrm{E}$ show the results regarding IL- 8 and IL-10 production, respectively. Neutrophil activation with GM-CSF and TNF- $\alpha$ resulted in a significative increase in IL- 8 production, while IL-15 and IFN- $\gamma$ have no effect. Pb18 alone also increased IL-8 production. Moreover, it was detected a tendency towards the fungus exhibit an additional effect in relation to this cytokine production in GM-CSFtreated cultures. None of the cytokines activated neutrophils for IL-10 release. This cytokine was only detected after $\mathrm{Pb} 18$ challenge. Interestingly, in most cultures, IL- 8 and IL-10 production induced by cytokines and/or $\mathrm{Pb}$ was diminished after TLR2 and mainly TLR4 blockade. These results suggest that IL-8 and IL-10 production by neutrophils in response to $P$. brasiliensis is dependent on TLR2 and mainly on TLR4.

\section{Discussion}

Neutrophils are essential components of the innate immune response against fungi, because they are the first immune cells to arrive at sites of infection, where they initiate antimicrobial and pro-inflammatory functions. A variety of receptors are involved in innate immune responses to fungal infections, including the mannose receptor, complement receptor 3 (CR3), TLR and $\beta$-glucan receptor $(\beta \mathrm{GR})$, and dectin-1 $[6,33,34]$. Then, neutrophils activated by some of these receptors may limit infection via fungus phagocytosis and by releasing 

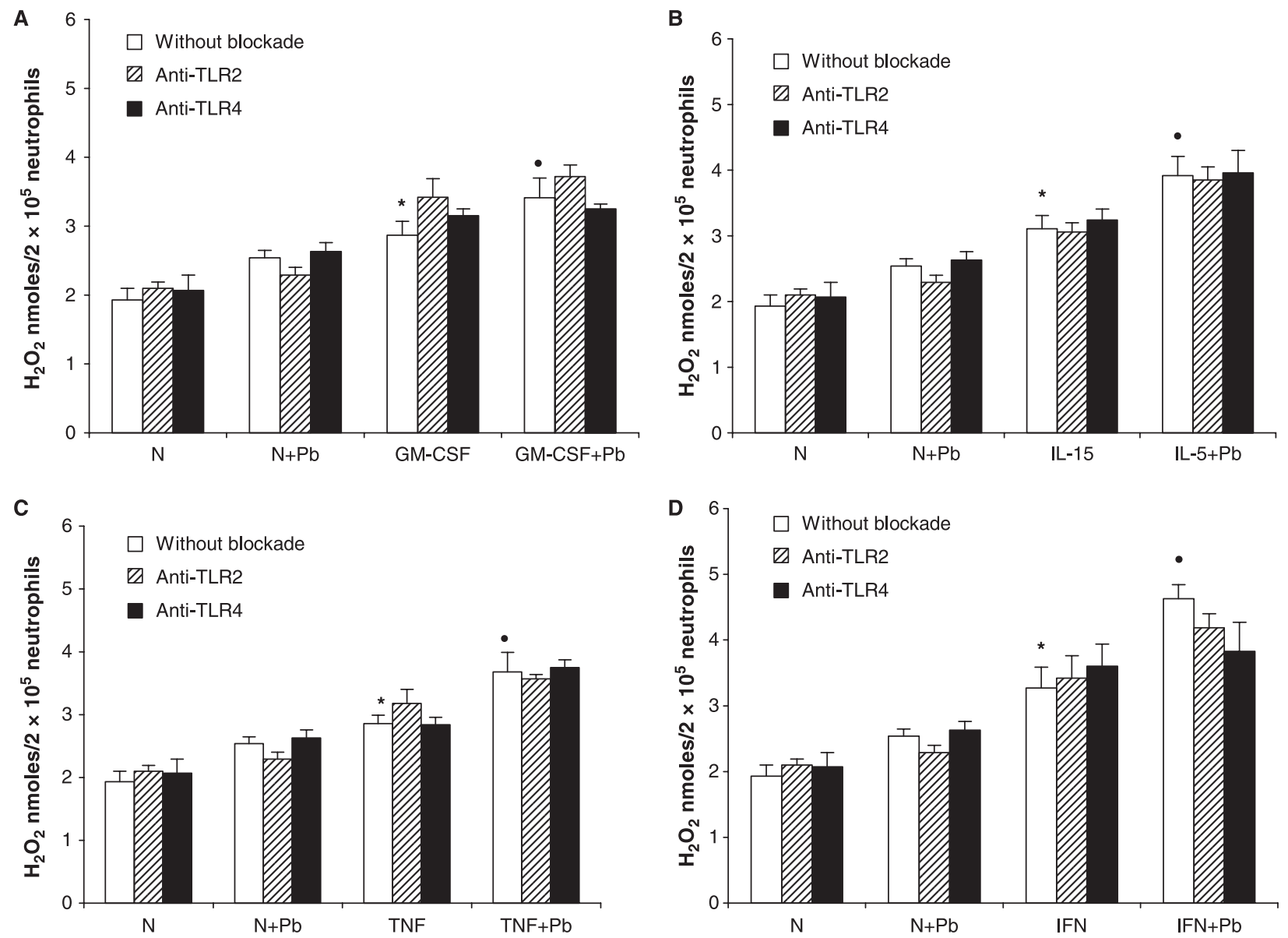

Figure 3 Role of TLR2 and TLR4 on $\mathrm{H}_{2} \mathrm{O}_{2}$ production. Cells were non-activated (N) or activated with the cytokines GM-CSF (100 U/ml) (A), IL$15(31.2 \mathrm{ng} / \mathrm{ml})(\mathrm{B}), \mathrm{TNF}-\alpha(250 \mathrm{U} / \mathrm{ml})(\mathrm{C})$ or IFN- $\gamma(50 \mathrm{U} / \mathrm{ml})$ (D) for $18 \mathrm{~h}$, in the absence or presence of anti-TLR2 or anti-TLR4 monoclonal antibodies, challenged or not with $\mathrm{Pb} 18$ for $4 \mathrm{~h}\left(2 \times 10^{4}\right.$ yeasts/ml:1:50 fungus/PMN ratio $)$ and evaluated for $\mathrm{H}_{2} \mathrm{O}_{2}$ production. The figure shows the mean \pm SEM obtained from 25 blood donors. Statistically significant differences between groups are indicated. $* P<0.01$ versus N; $\bullet P<0.001$ versus $\mathrm{N}$.

antimicrobial peptides, reactive oxygen intermediates and pro-inflammatory cytokines. Through chemokines production, they may recruit and activate other immune cells, and finally they have an important role on modulating adaptive immune response $[28,35]$. In this context, we aimed at evaluating TLR2 and TLR 4 expression on human neutrophils activated with the cytokines GMCSF, IL-15, TNF- $\alpha$ or IFN- $\gamma$ and challenged with a virulent strain of $\mathrm{Pb}$. Moreover, we asked if these receptors have a role on fungicidal activity, $\mathrm{H}_{2} \mathrm{O}_{2}$ and IL-6, IL-8, TNF- $\alpha$ and IL-10 production by activated and challenged cells. We detected that cells expressed both TLR2 and TLR 4 receptors and that this expression is significatively increased after GM-CSF, IL-15, TNF- $\alpha$ and IFN- $\gamma$ activation. These results are in agreement with others showing that human neutrophils express almost all known TLR, including TLR2 and TLR 4 [26], and that cytokines such as IL-1, and TNF- $\alpha$ [29], GM-CSF [24, 26, 31] and IFN$\gamma[31]$ increased this expression.
We also found that Pb18 increased TLR2 expression inducing an additional effect to that of cytokines. In contrast, $\mathrm{Pb}$ challenge resulted in a decrease in TLR 4 expression in non-stimulated neutrophils and cells treated with GM-CSF, TNF- $\alpha$ and LPS but not IL-15 and IFN- $\gamma$. A possible explanation for this result is that $\mathrm{Pb}$ can use TLR 4 to bind and enter inside neutrophils with consequent diminution in TLR4 levels on cells surface. This idea is supported by recent studies showing that TLR 4 and TLR2 are involved in $\mathrm{Pb}$ recognition by phagocytic cells [36].

As cytokines and/or Pb modulated TLR4 and TLR2 expression, we had interest in assessing whether these receptors are involved in neutrophil antifungal functions induced by these cytokines. We confirmed our previous studies showing that GM-CSF, IL-15, TNF- $\alpha$ and IFN- $\gamma$ activate human neutrophils inducing these cells to release higher $\mathrm{H}_{2} \mathrm{O}_{2}$ levels and fungicidal activity against $\mathrm{Pb}$ $[17,18,37]$. However, both $\mathrm{H}_{2} \mathrm{O}_{2}$ release and fungicidal 

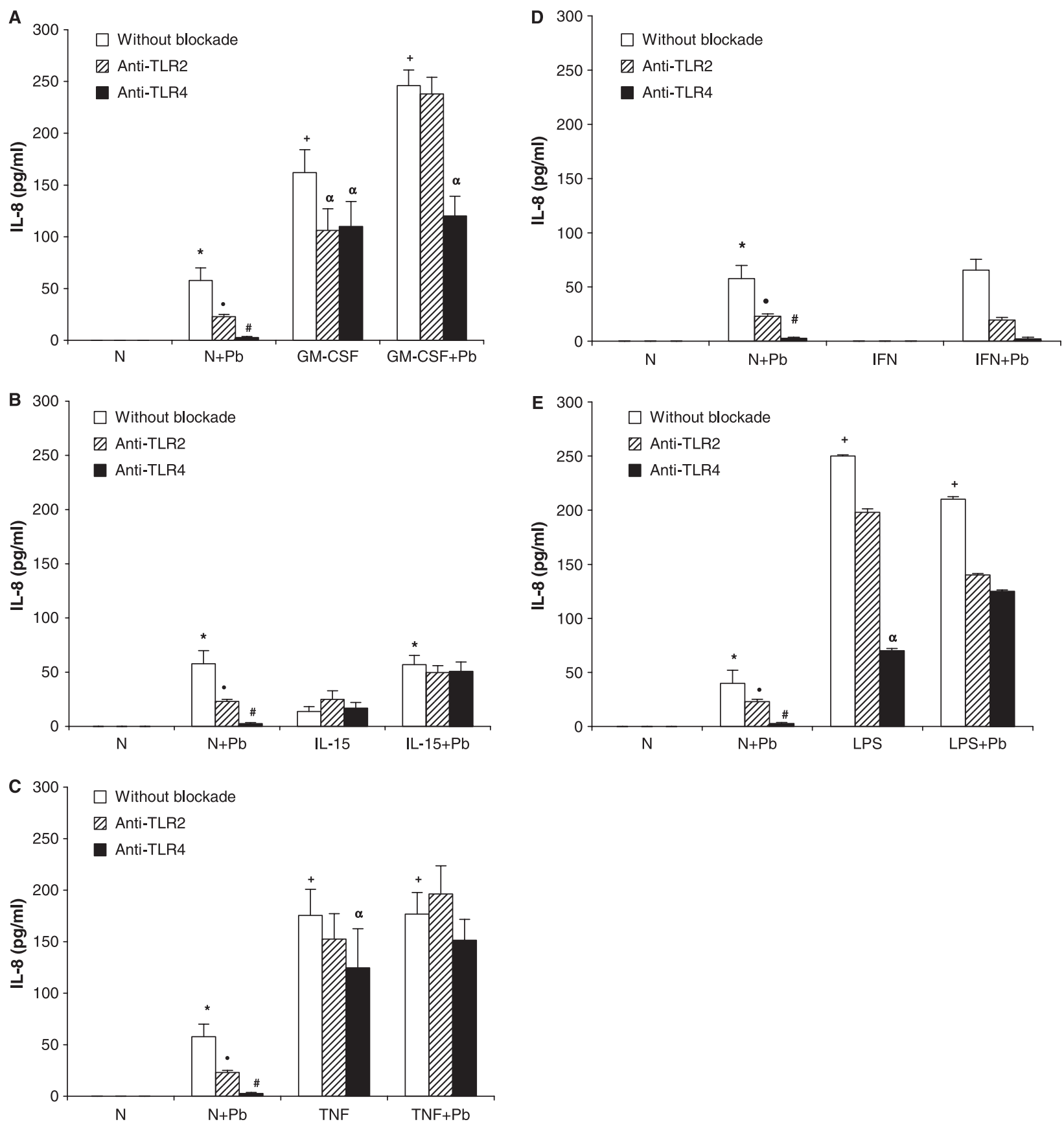

Figure 4 Participation of TLR2 and TLR4 on IL-8 production. Cells were non-activated (N) or activated with the cytokines GM-CSF (100 U/ml) (A), IL-15 (31.2 ng/ml) (B), TNF- $\alpha(250 \mathrm{U} / \mathrm{ml})(\mathrm{C})$ or IFN- $\gamma(50 \mathrm{U} / \mathrm{ml})(\mathrm{D})$ or LPS $(20 \mu \mathrm{g} / \mathrm{ml})$ for $18 \mathrm{~h}$, in the absence or presence of anti-TLR2 or anti-TLR 4 monoclonal antibodies, challenged or not with $\mathrm{Pb} 18$ for $4 \mathrm{~h}\left(2 \times 10^{4}\right.$ yeasts/ml:1:50 fungus/PMN ratio $)$ and evaluated for IL-8 production by ELISA. The figure shows the mean \pm SEM obtained from 25 blood donors. Statistically significant differences between groups are indicated. $* P<0.05$ versus $\mathrm{N} ;+P<0.01$ versus $\mathrm{N} ; \bullet P<0.05$ without blockade; $\# P<0.01$ without blockade; $\alpha P<0.001$ without blockade.

activity were not altered after TLR2 or TLR4 blockade showing the non-involvement of these receptors on these neutrophil activities. In agreement with our results, some studies have demonstrated a non-association between TLR2, TLR4 and fungal killing mechanisms. TLR4 was shown to be involved in protection in disseminated candidiasis. However, an association between this receptor and the mechanisms involved in Candida albicans killing, such as nitric oxide and superoxide anion, was not detected [38]. It was also shown that $\mathrm{Pb}$ yeasts are recognized by TLR 2 and TLR 4 resulting in increased phagocytic ability, NO secretion and fungal infection of macrophages. However, this effect did not result in fungal growth control [36]. 



Figure 5 Participation of TLR2 and TLR 4 on IL-10 production. Cells were non-activated $(\mathrm{N})$ or activated with the cytokines GM-CSF (100 U/ml) (A), IL-15 $(31.2 \mathrm{ng} / \mathrm{ml})(B)$, TNF- $\alpha(250 \mathrm{U} / \mathrm{ml})(\mathrm{C})$ or IFN- $\gamma(50 \mathrm{U} / \mathrm{ml})(\mathrm{D})$ or LPS $(20 \mu \mathrm{g} / \mathrm{ml})$ for $18 \mathrm{~h}$, in the absence or presence of anti-TLR2 or anti-TLR 4 monoclonal antibodies, challenged or not with $\mathrm{Pb} 18$ for $4 \mathrm{~h}\left(2 \times 10^{4}\right.$ yeasts/ml:1:50 fungus/PMN ratio $)$ and evaluated for IL-10 production by ELISA. The figure shows the mean \pm SEM obtained from 25 blood donors. Statistically significant differences between groups are indicated. $* P<0.05$ versus $\mathrm{N} ;+P<0.01$ versus $\mathrm{N} ; \bullet P<0.05$ without blockade; $\# P<0.01$ without blockade; $\alpha \alpha P<0.001$ without blockade.

Our results showing non-TLR2 or non-TLR 4 requirement for neutrophil killing mechanisms lead us to ask about the role of other receptors. Some studies have demonstrated the importance of mannose receptors [39, 40] and $\mathrm{CR} 3[40,41]$ in $\mathrm{Pb}$ phagocytosis. However, in our study, we can discard mannose receptors involvement, because this receptor is not expressed by human neutrophils. In contrast, studies have shown CR3 and dectin-1 expression by these cells [42, 43]. Moreover, dectin-1 is involved in $C$. albicans killing by human 
neutrophils [35]. Studies are being conducted in our laboratory to test the role of both CR3 and dectin-1 on fungal killing by human neutrophils.

We aimed at studying TLR2 and TLR4 requirement for IL-6, TNF- $\alpha$, IL-8 and IL-10 production. However, in our assays, neutrophils failed to release IL- 6 and TNF$\alpha$. Studies on the literature are controversial in relation to release of some cytokines by human neutrophils [44]. However, we are suggesting that lack of TNF- $\alpha$ and IL- 6 detection in our assays may be related to the period of culture for supernatant analysis (at least $18 \mathrm{~h}$ ). It is possible that this period was very late for TNF- $\alpha$ and IL-6 detection. Neutrophil activation with GM-CSF and TNF- $\alpha$ resulted in a significative increase in IL- 8 production, while IL-15 and IFN- $\gamma$ have no effect. Pb18 also increased IL-8 production. Moreover, there was a tendency towards $\mathrm{Pb} 18$ exhibiting an additive effect in GM-CSF-treated cultures. None of the cytokines activated neutrophils for IL-10 release. This cytokine was only detected after Pb18 challenge. Interestingly, in most assays, cytokines production was inhibited after receptors blockade. However, in relation to this effect, we must consider the most evident role of TLR4 in relation to TLR2. Some studies have shown TLR2 and TLR4 requirement for cytokines production by phagocytic cells in response to several stimuli, including fungi. TLR 4 is important for murine protection to $C$. albicans, by chemokines production such as KC and MIP-2, important for neutrophils influx [37]. Yet, in candidiasis, TLR2 is involved in TNF- $\alpha$, MIP-2 [45], IL-12, IFN- $\gamma$ [46] and IL-10 production [47]. In relation to paracoccidioidomycosis, our data showing preferential involvement of TLR4 in cytokines production are not in agreement with some studies showing that IL-10 production by dendritic cells or monocytes/neutrophils in response to $\mathrm{Pb}$ involves a preferential fungus recognition by TLR2 and dectin-1 instead of TLR 4 [48, 49]. The possible explanation for these differences might be related for differences in experimental protocols such as evaluation periods and the blockade or not of receptors.

In paracoccidioidomycosis, as in other infections, IL-10 production in response to $\mathrm{Pb}$ has been considered as an escape mechanism from host defence. High levels of this cytokine are detected in serum and culture supernatants of patients [50-52], and patients' monocytes spontaneously release high levels of this cytokine in vitro [53]. In experimental model of the mycosis, higher levels of IL10 were released by susceptible mice when compared to those of resistant mice [54]. In our laboratory, this cytokine has been demonstrated to inhibit $\mathrm{Pb}$ killing by IFN- $\gamma$-activated and TNF- $\alpha$-activated human monocytes and neutrophils $[36,55]$. However, we cannot discard the possible beneficial role of IL-10, controlling excessive inflammatory response induced by pro-inflammatory cytokines. In a recent study, less virulent strain of $\mathrm{Pb}$ was shown to be recognized by TLR 2 and dectin- 1 with consequent balanced production of TNF- $\alpha$ and IL-10. On the other hand, more virulent strain induced only TNF- $\alpha$ production. Thus, less virulent strain, by IL-10 production, induced a more controlled response, beneficial for the host [49].

Regarding IL-8, studies in our laboratory have demonstrated that this cytokine is involved in an anti-apoptotic effect of $\mathrm{Pb}$ on neutrophils, resulting in a delay on cells death, a process that could allow the fungus to survive intracellularly [56]. In addition, some studies showed that delayed neutrophil apoptosis induced by IL-8 involves signalling by TLR4 [57].

In summary, our data suggest that Pb18 uses TLR 4 to gain access to human neutrophils. However, this process does not result in an increase in killing mechanisms by these cells. On the other hand, it is involved in IL-8 and IL-10 production by human neutrophils in response to activator cytokines and/or $\mathrm{Pb}$. Considering that IL-10 and IL-8 are preferentially involved in escape mechanisms of $\mathrm{Pb}$ from neutrophil functions, our study points to the idea that $\mathrm{Pb}$ interaction with TLR4 on human neutrophils could be considered as a pathogenicity mechanism of this fungus, which would use host receptors of innate immunity to infect cells and to guarantee its own multiplication.

\section{Acknowledgment}

We thank Valéria Alves da Silva for helpful assistance in flow cytometry assays. Jossimara Polentini and Dra.Márcia Guimarães for helping in IL- 8 assays. This study was granted by CNPq - Senior Researcher fellow (process $\mathrm{n}^{\circ}$ 307009/207-6), Brazil

\section{Conflict of interest}

None.

\section{References}

1 Brummer E, Castaneda E, Restrepo A. Paracoccidioidomycosis: an update. Clin Microbiol Rev 1993;6:89-117.

2 Franco M, Peracoli MT, Soares A, Montenegro R, Mendes RP, Meira DA. Host-parasite relationship in paracoccidioidomycosis. Curr Top Med Mycol 1993;5:15-49.

3 Calich VLG, Russo M, Vaz CAC, Burger E, Singer-Vermes LM. Resistance mechanism to experimental Paracoccidiodes brasiliensis infection. Ciênc Cult 1994;46:455-61.

4 Musatti CC, Peraçoli MTS, Soares AMVC, Rezkallah-Iwasso MT. Cell-mediated immunity in patients with paracoccidiodomycosis. In: Franco MF, Lacaz CS, Restrepo A, Del Negro G, eds. Paracoccidiodomycosis. Flórida, USA: CRC Press, 1994:175-86. ISBN: 0-84934868-4.

5 Peraçoli MTS, Parise-Fortes M, Pereira da Silva MF, Montenegro MR. Natural killer cell activity in experimental paracoccidioidomycosis of the Syrian hamster. Rev Inst Med Trop São Paulo 1995;37:129-36. 
6 Calich VLG, Costa TA, Felonato M et al. Innate immunity to Paracoccidioides brasiliensis infection. Mycopathologia 2008;165:223-36.

7 Calich VL, Coppi Vaz CA, Burguer E. PMN chemotactic factor produced by glass-adherent cells in the acute inflammation caused by Paracoccidioides brasiliensis. J Exp Pathol 1985;66:585-94.

8 Souto JT, AlibertI JC, Campanelli AP et al. Chemokine production and leukocyte recruitment to the lungs of Paracoccidioides brasiliensis infect mice is modulated by interferon-gamma. Am J Pathol 2003;163:583-90.

9 Franco M, Montenegro MRG. Anatomia Patológica. In: Del Negro G, Lacaz CS, Fiorillo AM, eds. Paracoccidioidomicose. São Paulo: Sarvier-EDUSP, 1982;97-117.

10 Iabuki K, Montenegro MR. Experimental prarcoccidioidomycosis in the Syrian hamster morphology, ultrastructure and correlation of the lesions with presence of specific antigens and serum levels of antibodies. Mycopathologia 1979;67:131-41.

11 Calich VLG, Singer-Vermes LM, Siqueira AM. Susceptibility and resistence of inbred mice to Paracoccidioides brasiliensis. Br J Exp Pathol 1985;66:585-94.

12 Restrepo A, Vélez H. Efectos de la fagocitosis in vitro sobre el Paracoccidioides brasiliensis. Sabouraudia 1975;13:10-21.

13 Goihman-Yahr M, Essenfeld E, Albornoz MC et al. Defects on in vitro digestive ability of polymorphonuclear neutrophils in paracoccidioidomycosis. Infect Immun 1980;28:557-66.

14 McEwen JG, Brummer E, Stevens DA, Restrepo A. Effect of murine polymorphonuclear leukocytes on the yeast form of Paracoccidioides brasiliensis. Am J Trop Med Hyg 1987;36:603-8.

15 Meloni-Bruneri LH, Campa A, Abdalla DS, Calich VL, LenzI HL, Burger E. Neutrophil oxidative metabolism and killing of P. brasiliensis after air pouch infection of susceptible and resistance mice. J Leukoc Biol 1996;59:526-33.

16 Pina A, Saldiva PH, Restrepo LE, Calich VL. Neutrophil role in pulmonary paracoccidioidomycosis depends on the resistance pattern of hosts. J Leukoc Biol 2006;79:1202-13.

17 Rodrigues DR, Dias-Melicio LA, Calvi AS, Peraçoli MT, Soares AMVC. Paracoccidioides brasiliensis killing by IFN-gamma, TNFalpha and GM-CSF activated human neutrophils: role for oxygen metabolites. Med Mycol 2007; 45:27-33.

18 Tavian EG, Dias-Melicio LA, Acorci MJ, Bordon-Graciani AP, Peraçoli MTS, Soares AMV. Interleukin-15 increases Paracoccidioides brasiliensis killing by human neutrophils. Cytokine 2007;41:48-53.

19 Medzhitov R. Recognition of microorganisms and activation of the immune response. Nature 2007;449:819-26.

20 Roeder A, Kirschning CJ, Rupec RA, Schaller M, Weindl G, Korting HC. Toll-like receptors as key mediators in innate antifungal immunity. Med Mycol 2004;42:485-98.

21 Takeda K, Akira S. TLR signaling pathways. Semin Immunol 2004;16:3-9.

22 Beutler BA. TLRs and innate immunity. Blood 2009;113:1399407.

23 Van de Veerdonk FL, Kullberg BJ, van der Meer JW, Gow NA, Netea MG. Host-microbe interactions: innate pattern recognition of fungal pathogens. Curr Opin Microbiol 2008;11:305-12.

24 Kurt-Jones EA, Mandell L, Whitney C et al. Role of toll-like receptor-2 (TLR2) in neutrophil activation: GM-CSF enhances TLR2 expression and TLR2-mediated interleukin-8 response in neutrophils. Blood 2002;100:1860-8.

25 Fan J, Malik AB. Toll-like receptor-4 (TLR4) signaling augments chemokine-induced neutrophil migration by modulating cell surface expression of chemokine receptors. Nat Med 2003;9:477.

26 Hayashi F, Means TK, Luster AD. Tool-like receptors stimulate human neutrophil function. Blood 2003;102:2660-9.

27 Remer KA, Brcic M, Jungi TW. Toll-like receptor-4 is involved in eliciting an LPS-induced oxidative burst in neutrophils. Immunol Lett 2003;85:75-80
28 Bellocchio S, Montagnoli C, Bozza S et al. TLRs govern neutrophil activity in aspergillosis. J Immunol 2004;173:7406-15.

29 Muzio M, Bosisio D, Polentarutti N et al. Differential expression and regulation of toll-like receptors (TLRs) in human leukocytes: selective expression of TLR3 in dendritic cells. J Immunol 2000;164:5998-6004.

30 Flo TH, Halaas O, Torp S et al. Differential expression of Toll-like receptor 2 in human cells. J Leukoc Biol 2001;69:474-81.

31 O'Mahony DS, Pham U, Iyer R, Hawn TR, Liles WC. Differential constitutive and cytokine-modulated expression of human toll-like receptors in primary neutrophils, monocytes, and macrophages. Int $J$ Med Sci 2008;5:1-8.

32 Russo M, Teixeira HC, Marcondes MCG, Barbuto JAM. Superoxide-independent hydrogen peroxide release by activated macrophages. Braz J Med Biol Res 1989;22:1271-3.

33 Netea MG, Van der Meer JW, Kullberg BJ. Role of the dual interaction of fungal pathogens with pattern recognition receptors in the activation and modulation of host defence. Clin Microbiol Infect 2006;12:4004-9.

34 Dennehy KM, Brown GD. The role of the beta-glucan receptor Dectin-1 in control of fungal infection. J Leukoc Biol 2007;82:253-8.

35 Kennedy AD, Willment JA, Dorward DW, Williams DL, Brown GD, DeLeo FR. Dectin-1 promotes fungicidal activity of human neutrophils. Immunology 2007;37:467-78.

36 Calich VLG, Pina A, Felonato $\mathrm{M}$ et al. Toll-like receptors and fungal infections: the role of TLR2, TLR4 and MyD88 in paracoccidiodomycosis. FEMS Immunol Med Microbiol 2008;53:1-7.

37 Costa DL, Dias-Melicio LA, Acorci MJ et al. Effect of IL-10 on the Paracoccidioides brasiliensis killing by gamma-interferon activated human neutrophils. Microbiol Immunol 2007;51:73-80.

38 Netea MG, Van Der Graaf CA, Vonk AG, Verschueren I, Van Der Meer JW, Kullberg BJ. The role of Toll-like receptor (TLR) 2 and TLR 4 in the host defense against disseminated candidiasis. $J$ Infect Dis 2002;185:1483-9.

39 Almeida SR, Unterkircher CS, Camargo ZP. Involvement of the major glycoprotein (gp43) of Paracoccidioides brasiliensis in attachment to macrophages. Med Mycol 1998;36:405-11.

40 Jiménez Mdel P, Restrepo A, Radzioch D, Cano LE, Garcia LF. Importance of complement 3 and mannose receptors in phagocytosis of Paracoccidioides brasiliensis conidia by Nramp 1 congenic macrophages lines. FEMS Immunol Med Microbiol 2006;47:56-66.

41 Calich VLG, Kipnis TL, Mariano M, Fava Netto C, Dias da Silva W. The activation of complement system by Paracoccidioides brasiliensis in vitro. Its opsonic effect and possible significance for an in vivo model of infection. Clin Immunol Immunopathol 1979;12:20-30.

42 Munk ME, Kajdacsy-Balla A, Del Negro G, Cuce LC, Da Silva WD. Activation of human complement system in paracoccidioidomycosis. J Med Vet Mycol 1992;30:489.

43 Di Carlo FJ, Fiore JV. On the composition of zymosan. Science 1958;127:756-7.

44 Cassatella MA. Neutrophil-derived proteins: selling cytokines by the pound. Adv Immunol 1999;73:369-509.

45 Villamón E, Gozalbo D, Roig P et al. Myeloid differentiation factor 88 (MyD88) is required for murine resistance to Candida albicans and is critically involved in Candida-induced production of cytokines. Eur Cytokine Netw 2004;15:263-71.

46 Villamón E, Gozalbo D, Roig P, O'Connor JE, Fradelizi D, Gil ML. Toll-like receptors 2 is essential in murine defenses against Candida albicans infections. Microbes Infect 2004;6:1-7.

47 Netea MG, Sutmuller R, Hermann C et al. Toll-like receptor 2 suppress immunity against Candida albicans through induction of IL-10 and regulatory T cells. J Immunol 2004;172:3712-8.

48 Ferreira KS, Bastos KR, Russo M, Almeida SR. Interaction between Paracoccidioides brasiliensis and pulmonary dendritc cells induces 
interleukin -10 production and toll-like receptor-2 expression: possible mechanism of susceptibility. J Infect Dis 2007;196:1108-15.

49 Bonfim CV, Mamoni RL, Souza MH, Blotta L. TLR2, TLR4 and dectin-1 expression in human monocytes and neutrophils stimulated by Paracoccidioides brasiliensis. Med Mycol 2009;17:1-12.

50 Benard G, Romano CC, Cacere CR, Juvenale M, Mendes-Giannini MJ, Duarte AJS. Imbalance of IL-2, IFN- $\gamma$ and IL-10 secretion in the immunosupression associated with human paracoccidioidomycosis. Cytokine 2001;13:248-52.

51 Formari MC, Bava AJ, Guereno MT et al. High serum interleukin10 and tumor necrosis factor alpha levels in chronic paracoccidioidomycosis. Clin Diagn Lab Immunol 2001;8:1036-8.

52 Oliveira SJ, Mamoni RL, Musatti CC, Papaiordanou PMO, Blotta MHSL. Cytokines and lymphocyte proliferation in juvenile and adult forms of paracoccidioidomycosis: comparison with infected and non-infected controls. Microbes Infect 2002;4:139-44.
53 Peraçoli MT, Kurokawa CS, Calvi SA et al. Production of pro and anti-inflammatory cytokines by monocytes from patients with paracoccidioidomycosis. Microbes Infect 2003;5:413-8.

54 Calich VLG, Kashino SS. Cytokines produced by susceptible and resistant mice in the course of Paracoccidioides brasiliensis infection. Braz J Med Biol Res 1998;31:615-23.

55 Soares AMVC, Silva WB, Rodrigues DR. IL-10 but not TGF- $\beta$ inhibits Paracoccidioides brasiliensis killing by human activated monocytes. Annu Rev Biomed Sci 2002;Special issue:89.

56 Acorci MJ, Dia-Melicio LA, Golim MA, Bordon-Graciani AP, Peraçoli MTS, Soares AMVC. Inhibition of human neutrophil apoptosis by Paracoccidioides brasiliensis: role of interleukin-8. Scand J Immunol 2008;69:73-9.

57 Sabroe I, Prince LR, Jones EC et al. Selective roles for Toll-like receptor (TLR) 2 and TLR4 in the regulation of neutrophil activation and life span. J Immunol 2003;170:5268-75. 